\title{
O realismo em questão
}

O modernismo na literatura se perfilou de modo exemplar em oposição ao realismo histórico do século 19 e manteve a distancia crítica seus herdeiros do início do século XX, os diferentes novos realismos. Se o realismo entendia seu papel histórico de responsabilidade política e ética vinculado ao compromisso referencial, o modernismo via na quebra experimental das formas realistas um acesso privilegiado $\mathrm{e}$ potencialmente utópico às camadas de realidade excluídas da imagem representativa do mundo.

Para entender o papel do realismo na literatura contemporânea é necessário reconhecer a inversão, durante a segunda metade do século passado, desses paradigmas contrapostos na literatura ocidental em geral e na brasileira em particular. Tratou-se de uma mudança de ótica que permite de novo ver no realismo um grande desafio para uma literatura ameaçada a sucumbir sob a pressão da realidade midiática. Numa situação em que a realidade crescente da mídia causa uma ficcionalização constante das representações do mundo e ameaça liquidar a potencia libertária do imaginário literário e artístico. Diante disso as formas experimentais se conciliam com a intenção representativa na finalidade de expressar uma realidade própria da literatura em sua inserção no mundo atual. Motivações políticas e estéticas entram de novo em diálogo à procura de um diferencial ético que possa legitimar a literatura diante do tsunami representativo da mídia.

Os experimentos pós-modernos da década de 80 já permitiram a reconciliação com a narrativa figurativa e com os grandes gêneros modernos de romance e conto e deram assim um primeiro passo nessa direção aliado ao reconhecimento que a representação histórica pudesse ser reconfigurada de modo interessante dentro da subversão literária das linguagens.

Em alguns casos contemporâneos vemos por sua vez a reciclagem de experiências modernistas de escrita dentro da intenção de criar expressões diretas e impactantes de realidades que normalmente não ganham articulação própria na literatura. Assim, o realismo hoje aparece numa estranha combinação entre representação e não representação, por um lado visível na retomada de uma herança de diferentes formas históricas e por outro na atenção em relação à literatura em sua capacidade de intervir na realidade receptiva e de agenciar experiências perceptivas, afetivas e performáticas que se tornam reais.

Há hoje escritores que apostam na reformulação direta do compromisso social e insistem numa ficção, frequentemente herdeira do realismo, que possa ter força de intervenção na realidade. Tais escritores pretendem criar testemunhos e escrever de modo a interpretar e refletir sobre a história contemporânea nacional e global, ocupando-se de temas que preocupam parte significativa da sociedade em formatos que facilmente encontram eco e criam impactos na mídia e na esfera pública. Essa ansiedade

\footnotetext{
Revista Escrita

Rua Marquês de São Vicente, 225 G ávea/ RJ CEP 22453-900 Brasil

Ano 2012. Número 14. ISSN 1679-6888.

escrita@puc-rio.br
} 
de ganhar presença é um sintoma da vontade de estabelecer uma nova aliança entre a literatura e a sociedade e seus problemas.

$\mathrm{O}$ uso das formas breves e híbridas, a adaptação de uma linguagem curta e fragmentária em narrativas complexas e não-lineares e o namoro com a crônica jornalística são alguns dos experimentos de escrita que devemos entender à luz de um projeto realista contemporâneo, porém um projeto que não aceita necessariamente as estreitas premissas representativas dos realismos históricos. Expressam entretanto a urgência contemporânea de falar sobre e com o real e de alcançar um efeito de presença crítica que abre caminho para a retomada de projetos históricos de engajamento e intervenção. Para alguns escritores contemporâneos, os efeitos de "presença" se aliam à conjunção de conteúdos históricos chocantes de uma tradição de narrativa urbana com origens na geração de contistas da década de 70 e uma eficiência estética buscada numa linguagem de efeito e num estilo mais enfático. Para outros o caminho ficcional retoma certo memorialismo à procura da memória familiar íntima ou por encenação da história mínima de vivência biográfica. Nessa perspectiva a presença vira sinônimo de intimidade e aproximação literária ao mais cotidiano, autobiográfico e banal. Em comum para todos é o reconhecimento de que a literatura não se faz apenas na reprodução das formas e dos estilos à disposição na tradição. Para virar literatura e torna-se real a escrita precisa nos permite perceber, sentir e pensar. Assim a realidade da literatura se confunde com o realismo que abraça ou que cria no seu próprio fazer.

Karl Erik Schollhammer

Julho 2012

Revista Escrita 